\title{
Review \\ Laser-induced fluorescence technique for DNA and proteins separated by capillary electrophoresis
}

\author{
Yang-Wei Lin, Tai-Chia Chiu, Huan-Tsung Chang* \\ Department of Chemistry, National Taiwan University, 1, Section 4, Roosevelt Road, Taipei, Taiwan
}

\begin{abstract}
Recent developments in capillary electrophoresis (CE) in conjunction with laser-induced fluorescence (LIF) using long-wavelength (maximum excitation wavelength $>500 \mathrm{~nm}$ ) dyes are reviewed. These dyes are particularly of interest when conducting the analyses of biopolymers by CE-LIF using He-Ne lasers. These systems are benefited from low background, low costs, easy maintenance, and compactness. Derivatizations of DNA and proteins with fluorescent or nonfluorescent chemicals can be carried out prior to, during, or after separations. With the advantages of sensitivity, rapidity, and high efficiency, the applications of CE-LIF to the analysis of polymerase chain reaction products, DNA sequencing, trace analysis of proteins, and single cell analysis have been presented.
\end{abstract}

(C) 2003 Elsevier B.V. All rights reserved.

Keywords: Reviews; DNA; Proteins

\section{Contents}

1. Introduction .....

2. Analysis of DNA.......

2.1. Non-intercalating dyes......

2.2. Intercalating dyes

2.2.1. Mono-intercalating dyes

2.2.2. Bis-intercalating dyes

2.2.2.1. EthDs.

2.2.2.2. Cyanine family

3. Analysis of proteins

3.1. Rhodamine and cyanine families ...

3.2. Solvatochromic dyes

3.3. Albumin blue series

3.4. Phycobiliproteins

4. Conclusions .... 


\section{Introduction}

Capillary electrophoresis (CE) in conjunction with laser-induced fluorescence (LIF) provides utmost speed, sensitivity and resolving power and has documented for the analyses of a wide number of solutes. Most successful examples include single molecule detection, DNA sequencing, analysis of polymerase chain reaction (PCR) products, single cell analysis, and analyses of proteins and small solutes [1-9]. For the past years, we have witnessed a dramatic impact of capillary array electrophoresis (CAE) on sequencing human genomes and drug screening [10,11]. It is thus our belief that techniques based on CE-LIF are likely to be suitable for sequencing further genomes for comparison, genetic testing and diagnostic, as well as proteomics that now represent major pressure for the development of even higher throughput and more robust analytical technologies.

Lasers with distinct advantages of coherence, high intensity, and single wavelength have been found suitable for CE. To achieve low limits of detection (LODs), it is extremely important to minimize the stray light from optics and Rayleigh and Raman scattering of the solvent molecules. Lasers with small spots and easily focused are definitely much better than conventional light sources in this aspect. Several LIF designs, including cross-beam excitation [12], epi-illumination [13], axial-beam excitation [14], and sheath-flow cuvette [15], have been tested and found effective to induce fluorescence, to collect fluorescence, and to minimize the background. Although the systems based on cross-beam excitation are popular due to simplicity, CE-LIF using a sheath-flow cuvette provides better sensitivity mainly because of a minimum Rayleigh scattering from the capillary wall and Raman scattering from water.

A variety of lasers have been employed for the analyses of DNA and proteins by CE-LIF with varying degrees of success [16-19]. These include $\mathrm{KrF}$ excimer laser at $248 \mathrm{~nm}, \mathrm{Nd}$ :YAG laser at 266 $\mathrm{nm}, \mathrm{Ar}^{+}$lasers at $275 \mathrm{~nm}, 488 \mathrm{~nm}$, and/or $514 \mathrm{~nm}$, $\mathrm{He}-\mathrm{Cd}$ lasers at 320 and $442 \mathrm{~nm}$, and $\mathrm{He}-\mathrm{Ne}$ lasers at 543.6, 592.6, and $633 \mathrm{~nm}$. Because some proteins have native fluorescence around $310 \mathrm{~nm}$ when excited by UV light, the first three lasers have been used for trace analysis of proteins [16-18]. However the systems are expensive and/or maintenance is needed and costly. Short lifetimes of $\mathrm{He}-\mathrm{Cd}$ lasers are problematic. Thus, we do not doubt the superiority of $\mathrm{Ar}^{+}$lasers at $488 \mathrm{~nm}$ and $514 \mathrm{~nm}$ and $\mathrm{He}-\mathrm{Ne}$ lasers over the others for the analyses of DNA and proteins, mainly because they are low costly, stable, and compact. Although these two types of lasers provide the advantages of relatively low background from intrinsic fluorescence of the matrix and scattered lights, they are not a suitable light source for exciting most proteins and DNA to induce native fluorescence. To overcome this disadvantage, derivatization of the analytes with a suitable chemical is required. When derivatization is slow, a pre-column mode is commonly carried out to achieve high yields in spite of the risk of contamination and loss of dynamic information. If derivatization is fast but could causes problems on separation, a post-column mode is a better choice. However, an extra connection is usually needed, leading to peak broadening and difficulty for automation. For a fast reaction without causing loss of resolution, an oncolumn mode is popular because derivatization simply takes place during separation. When the labeling agent is fluorescent, a plug of a solution containing the agent is injected after or prior to sample injection, depending on its relative mobility to that of the analytes. For the sake of sensitivity, the fluorescent complex must be stable during the separation. When the mismatch of the system conductivities occurs, efforts must be made to minimize peak broadening. Particular attentions must also be paid to the effect of plug length on sensitivity, speed, and resolution. When the dye is nonfluorescent, it can be simply added to the background electrolyte. The dye concentration must be carefully evaluated in order to optimize resolution and sensitivity because the mobility and intensity of the fluorescent complex is generally sensitive to the concentration ratio of dye/ analyte. It is important to point out that this mode is suitable for both weak and strong complexes.

There are a number of fluorescent and nonfluorescent reagents that are commercially available and conveniently used for labeling DNA and proteins. The handbook of fluorescent probes and research chemicals produced by Molecular Probes is a good source for the information of these reagents and labeling conditions [20]. Structures of some common long-wavelength dyes for the analyses of DNA and proteins are depicted in Fig. 1. With respect to speed 

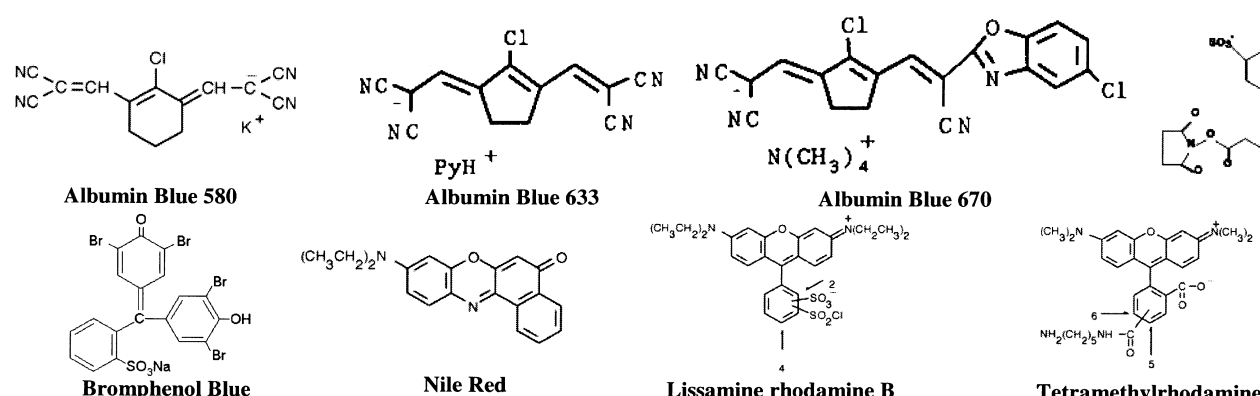

$\mathbf{C y - 5}$

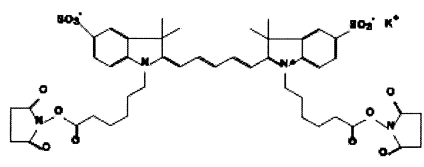

Bromphenol Blue

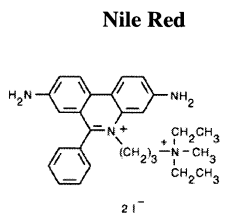

Propidium Iodide

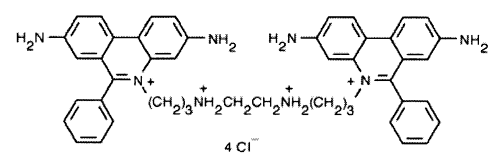

Ethidium homodimer-1
Tetramethylrhodamine

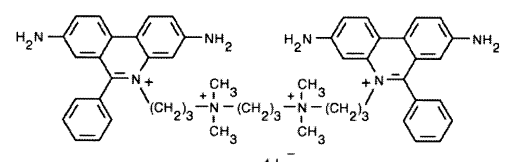

Ethidium homodimer-2

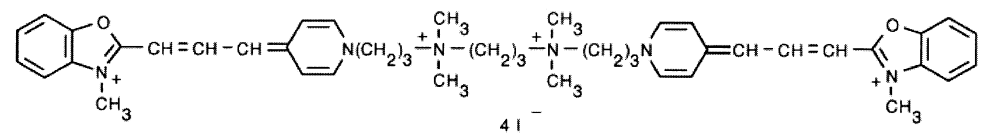

POPO-3 iodide

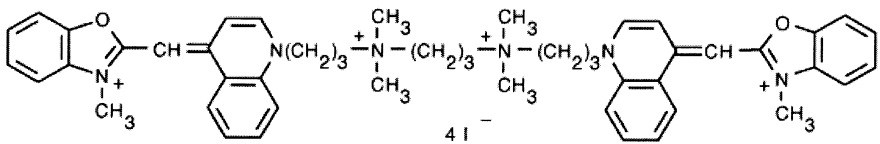

YOYO-1 iodide

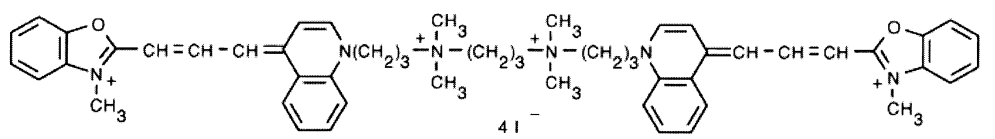

YOYO-3 iodide

Fig. 1. Structures of some common long-wavelength dyes used for the analyses of DNA and proteins..

and sensitivity, derivatization should be fast as well as complete and thus formed complexes should be stable and highly fluorescent. These requirements are extremely important when monitoring dynamic changes of proteins at the single cell level. When analyzing highly complicated samples like biological samples, the derivatization should be selective or sometimes specific in order to reduce possible interferences form unwanted signals in the electropherogram.

Driven by the human genome project and proteomics for many years, numerous papers dealing with the analyses of biopolymers by CE-LIF have been published, including several review articles [21-25]. With the advantages addressed above, the two most popular types of lasers used for the analyses of DNA and proteins are $\mathrm{Ar}^{+}$and $\mathrm{He}-\mathrm{Ne}$ lasers that are inexpensive. $\mathrm{He}-\mathrm{Ne}$ lasers are attractive, especially for those who are looking for a cost-effective LIF detection system. The costs of $\mathrm{He}-\mathrm{Ne}$ lasers $(2 \mathrm{~mW})$ are around US $\$ 800$, about nine-times lower than that of $\mathrm{Ar}^{+}$. In this article, we focus on approaches to the analyses of DNA and proteins by CE-LIF using long-wavelength dyes. Our reference list is certainly biased by our own interests and much important work may not be included.

\section{Analysis of DNA}

CE has been applied to DNA sequencing, analysis of PCR products, as well as genotyping like single nucleotide polymorphisms (SNPs). There have been 
several excellent reviews dealing with the theory of DNA separation by CE [26-28]. Ultraviolet absorbance detection mode has shown useful for the analysis of DNA mainly because the system is simple and DNA has a great molar absorptivity at the wavelength of $260 \mathrm{~nm}$. On the other hand, LIF has established a sensitive detection mode for DNA sequencing, single molecule detection, and trace analysis of DNA. In addition, labeling of DNA with different dyes based on Sanger reaction provides the advantage of high throughput and has been applied to DNA sequencing in CAE systems [29,30]. These techniques have played a crucial role in completing the human genome sequences.

\subsection{Non-intercalating dyes}

Covalent labeling of DNA with a highly fluorescent and stable dye, such as Lissamine rhodamine-B sulfonyl chloride (Lissamine 20), tetramethylrhodamine isothiocyanate (TRITC), sulfoindocyanine succinimidyl ester (Cy5) is common for DNA analysis by CE-LIF. Examples include DNA sequencing and single-strand conformation polymorphisms (SSCPs) [29,31-34]. Dyes may be coupled to DNA through sites present naturally such as amino groups on the bases, hydroxyl groups on the sugars and phosphate groups, both terminal and internal, or through some other reactive linker groups, such as primary amines, thiols, or aldehydes. When working in a pre-column mode, the main advantages include: (1) conditions for derivatization and separation can be independently chose for optimum sensitivity and separation efficiency; (2) conditions can be set to allow complete reactions for numerous analytes without quantitative bias; (3) the separation system is relatively simple and flexible. However, attentions sometimes must be paid to overcome problems associated with poor labeling efficiency and multiple labeling of the analytes.

Although rhodamine dyes are less bright than fluorescein, background noise source is easily avoided when operating at longer wavelengths. This advantage has been taken to perform DNA sequencing by $\mathrm{CE}$ and $\mathrm{CAE}$. For example, conventional FAM (5-carboxyfluorescein)/JOE (6-carboxyfluorescein)/TAMRA (6-carboxy- $N, N, N^{\prime} N^{\prime}$-tetramethylrhodamine)/ROX (6-carboxyrhodamine) labeled
(-21) M13 universal primers from Applied Biosystems/Perkin-Elmer have been commonly used for DNA sequencing by CE-LIF [35,36]. Another example is the use of FAM/TET (6-carboxy-4,7,2', $7^{\prime}$-tetrachlorofluorescein)/HEX (6-carboxy-4,7,2', $4^{\prime}, 5^{\prime}, 7^{\prime}$-hexacholofluorescein)/TAMRA labeled DNA primers for DNA sequencing in a 91-capillary array [37]. Although these techniques have demonstrated in DNA sequencing with varying degrees of success, the influence of fluorophor dye labels on the migration behavior of DNA must be carefully considered in order to achieve reproducible and precise short tandem repeat (STR) genotyping [38].

Fluorescence resonance energy transfer in conjunction with $\mathrm{CE}$ or $\mathrm{CAE}$ using suitable primers labeled with dyes such as FAM and JOE at the 5' end as a donor and other dyes such as rhodamine $6 \mathrm{G}$ and TAMRA attached to a modified thymidine residue within the primer sequence as acceptor has been demonstrated for DNA sequencing $[29,39]$. The higher intensity of the energy transfer primers allows DNA sequencing with minute amount of DNA templates and employment of a single laser. Alternatively, $\mathrm{CE}$ in conjunction with time-resolved fluorescence detection using multiplex dyes including rhodamine derivatives has shown promise for DNA sequencing [40-42]. The advantage of these methods is the possibility of using a single diode laser for DNA sequencing, mainly due to the similar absorption and emission characteristics but distinct fluorescence lifetimes of these so-called multiplexed dyes.

Using secondary anti-mouse antibody labeled with rhodamine has demonstrated for the determination of thymine glycol in DNA after irradiation of human cells with a clinical dose of 2 Gray (Gy) [43]. This method allows a specific detection of thymine glycol, with an LOD of $\sim 10^{-21}$ mol. Texas Red, with broad emission above $600 \mathrm{~nm}$, belongs to the rhodamine family and is relatively hydrophilic compared to rhodamine. It has been used in the analysis of SSCP of K-ras genes [44]. Tseng et al. have demonstrated on-line concentration and separation of GeneScan 1000 ROX, fluorescently-labeled DNA ladders that allow determination of the fragment lengths between 100 and 900 base pairs under denaturing conditions when loading in the same capillary injection as the experimental samples [45]. The DNA fragments slow down due to increases in the viscosity as well 
as sieving, and thus stack when migrating from the sample zone to poly(ethylene oxide) (PEO) solution. Fig. 2 depicts the separation of $1.54 \mu \mathrm{l}$ of 100 -fold diluted GeneScan 1000 ROX in $1.5 \%$ PEO, with a 265 -fold sensitivity enhancement compared to that injected at $25 \mathrm{~V} / \mathrm{cm}$ for $10 \mathrm{~s}$. It is noted that the migration order is reversed to that using deactivated capillary column because DNA migrates against the electroosmotic flow (EOF).

\subsection{Intercalating dyes}

Chemicals that are not or weakly fluorescent and become strongly fluorescent upon forming complexes are excellent for CE-LIF because of low background. This advantage has been well demonstrated in the analysis of DNA, in which intercalating dyes in the background electrolytes (polymer solution) form stable complexes with double-stranded (ds) DNA during electrophoretic separations [46-49].
Common intercalating dyes include ethidium homodimer (EthD), benzoxazolium-4-pyridinium dimer (POPO-3), benzoxazolium-4-quinolinium dimer (YOYO-1), benzothiazolium-4-quinolinium dimer (TOTO-1), and ethidium bromide (EtBr), which all have planar aromatic or hetero-aromatic rings that can be inserted between adjacent base pairs of dsDNA. Once binding to DNA, free rotation of the dye molecules reduces, thereby increasing fluorescence intensity. The characteristics of intercalating dyes include high molar absorptivity, very low intrinsic fluorescence, large fluorescence enhancement upon binding to DNA, and moderate to high affinity for DNA.

\subsubsection{Mono-intercalating dyes}

$\mathrm{EtBr}$ and propidium iodide (PI) are structurally similar and both have one phenanthridinium ring, while the last is more water soluble and less mem-

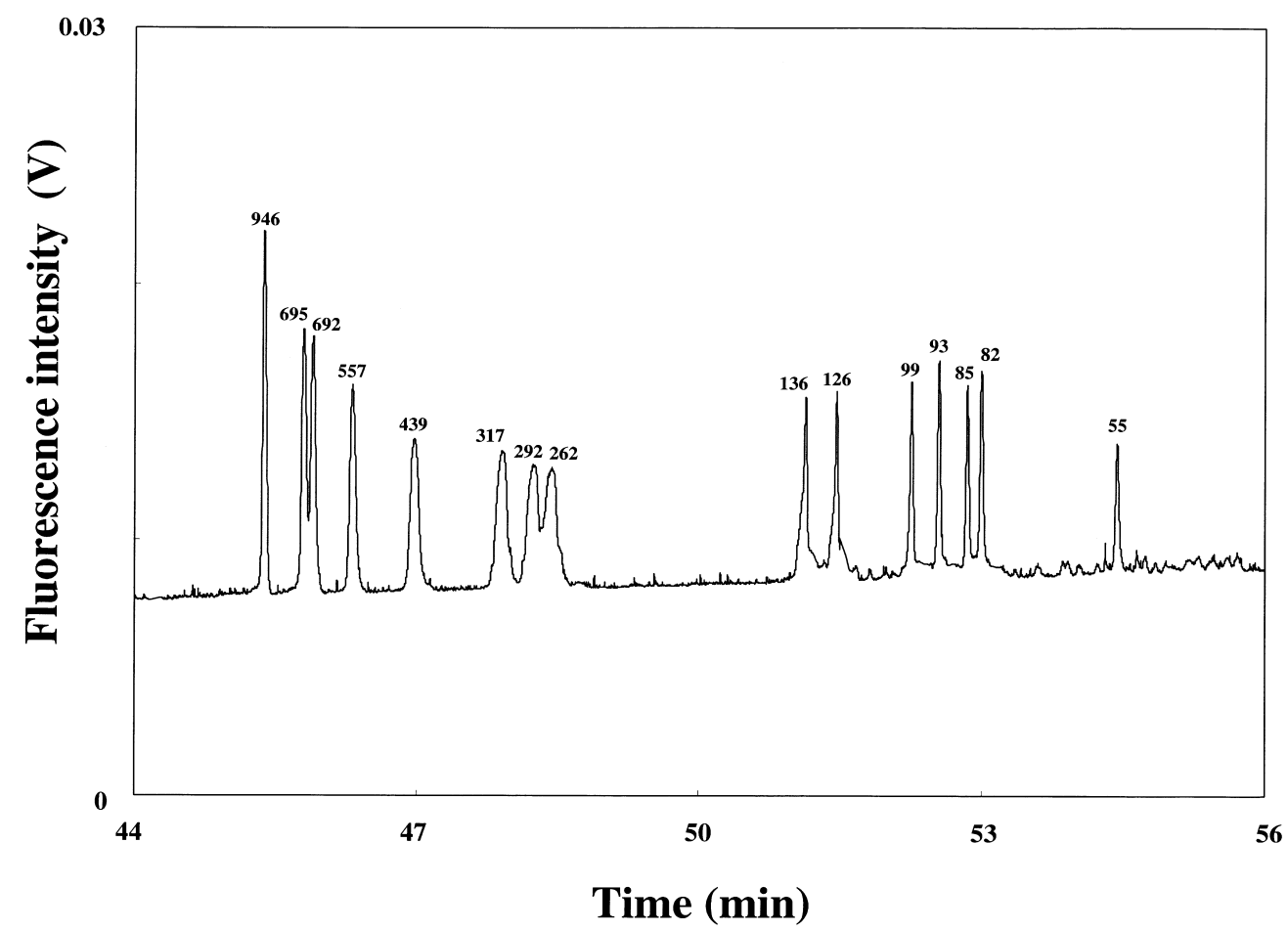

Fig. 2. Separation of a 100-fold diluted GeneScan 1000 ROX sample in the presence of EOF at $334 \mathrm{~V} / \mathrm{cm}$ using $1.5 \%$ PEO prepared in $200 \mathrm{~m} M$ Tris-borate (TB) buffers, $\mathrm{pH}$ 9.0. Reproduced with permission from Ref. [45]. 
brane permeant. They both bind with little or no sequence preference at a stoichiometry of one dye per 4-5 base pairs of DNA, with fluorescence enhancements of 20- to 30-fold. Once binding to DNA, their excitation and emission wavelength maxima shift about $\sim 30-40 \mathrm{~nm}$ to the red and $\sim 15$ $\mathrm{nm}$ to the blue, respectively.

Although EtBr does not bind DNA very specifically and strongly, it has been one of the most popular dyes used in DNA analysis, mainly because it is low costly and the reaction is very fast. In CE, $\mathrm{EtBr}$ is generally added to the polymer solution and forms fluorescent complexes with DNA immediately during separation [50,51]. When binding to cationic EtBr, the mobility of DNA decreases and the structure of DNA becomes stiffer, depending on the concentration of $\mathrm{EtBr}$ and DNA sizes as well as conformation. It has been suggested that the mole ratio of EtBr/DNA 5:1 is suitable for dsDNA. CELIF using EtBr has been applied to the separation of different conformational DNA [51]. Supercoiled plasmids migrate more slowly than linear dsDNA of the same size using a deactivated capillary, presumably because plasmid migrates as an elastic rod, while dsDNA migrates as a wormlike chain. Interestingly, the migration of supercoiled plasmids does not follow the elastic rod model in the presence of EOF. Zabzdyr et al. performed reverse transcriptase (RT)
PCR prior to performing CE-LIF for the analysis of $\beta$-actin expression in single $\mathrm{LNCaP}$ (prostate cancer) cells [52]. To improve sensitivity, Huang et al. have developed on-line concentration techniques for trace analysis of DNA using PEO solution containing EtBr in the presence of EOF [53]. This technique allows a maximum injection volume of $5 \mu \mathrm{l}$ and greater than 400 -fold improvements in the sensitivity compared to that by conventional injections (ca. $36 \mathrm{nl}$ ). One feature of this method is no requirement for tedious sample treatment prior to the analysis of large volumes of DNA prepared in high-conductivity media. Importantly, this technique allows the analysis of PCR products after only 17 cycles, with the advantage of rapidity. The same group has also developed gradient techniques using different concentrations of $\mathrm{PEO}$ and $\mathrm{EtBr}$ for separating a mixture of pBR322/HaeIII, pBR328/Bgll, and pBR 328/ Hinf 1 digests, with optimum resolution, speed, and sensitivity [54,55]. Fig. 3 represents a scheme showing the use of a series of syringes to inject different PEO solutions to the tube, in which PEO solutions enter the capillary by EOF during separation. To achieve optimized resolution and speed for the DNA with a wide size rang [e.g., 8 to 2176 base pairs (bp)], the PEO and EtBr concentrations start from low (e.g., $0.5 \%$ PEO containing $0.5 \mu \mathrm{g} / \mathrm{ml} \mathrm{EtBr}$ ) to high (e.g., 2.0\% PEO containing $5 \mu \mathrm{g} / \mathrm{ml} \mathrm{EtBr)} \mathrm{[54].}$

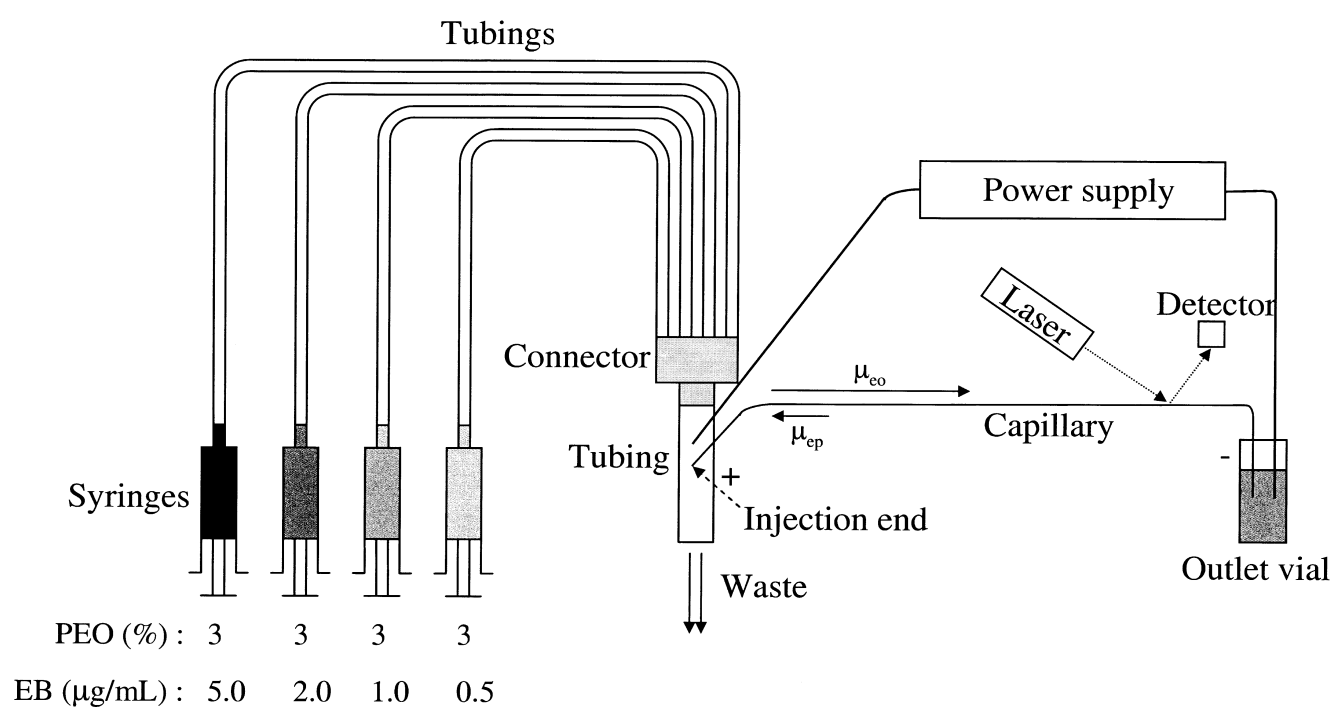

Fig. 3. Schematic diagram of the setup for gradient CE. Reproduced with permission from Ref. [55]. 


\subsubsection{Bis-intercalating dyes}

Bis-intercalating dyes can be applied to the analysis of dsDNA, single-stranded (ss) DNA, as well as RNA and bind strongly to DNA through their two planar rings. Thus, adding excess bis-intercalating dyes in the background electrolyte is prevented, leading to very low background. There are two common groups of bis-intercalating dyes: EthD and cyanine family. Compared to mono-intercalating dyes, bis-intercalating dyes generally provide better sensitivity for DNA analysis but are more expensive. Sometimes, band broadening is found due to different binding modes such as noncooperative binding between the non-intercalated ring and the anionic phosphate ion of DNA, dye-dye, or cooperative binding involving non-intercalated rings [48]. To minimize the interference from side products, the concentration ratio between dye/DNA and other reaction conditions such as ionic strength and reaction times must be carefully controlled.

2.2.2.1. EthDs. The fluorescence enhancements of EthD-1 and EthD-2 upon complexation with dsDNA, ssDNA, RNA, and oligonucleotides are greater than 40-fold, which is independent of base compositions or sequences [56]. Although one molecule of both EthD-1 and EthD-2 binds per 4-5 bp in dsDNA, the affinity of EthD-2 for DNA is about twice that of EthD-1. These dyes have been employed for the analysis of DNA restriction fragments and duck hepatitis B virus using a post-column sheath-flow cuvette. Owing to a high signal and small noise, this system allows a concentration LOD of $3.9 \cdot 10^{-16} \mathrm{M}$ for the analyte [57].

2.2.2.2. Cyanine family. There are two series of bis-intercalating dyes in the cyanine family, which are TOTO series, including TOTO, YOYO, and BOBO, as well as SY-TO series, including SYTOX Orange, SYTO 82, and SYTO 25. TOTO series are symmetric dimmers with four positive charges and are among the most sensitive and highest affinity fluorescent probes available for nucleic staining $[58,59]$. It is interesting to note that the optical properties of TOTO series can be tuned by simply changing the aromatic rings and the number of carbon atoms linking the cyanide monomers. The excitation wavelengths of TOTO-3 series (three carbons linking the cyanide monomers) are longer compared to that of TOTO-1 series, and thus they are more suitable for the DNA analysis when using a $\mathrm{He}-\mathrm{Ne}$ laser. On the other hand, TOTO-1 series are suitable for DNA analysis when an argon ion laser at $488 \mathrm{~nm}$ is available. TOTO series work not only for dsDNA, but also for ssDNA and RNA. The formation constants of these dyes for dsDNA are larger than $10^{8}$ and one dye molecule is incorporated with 10 base pairs. With such high formation constants and relatively high costs (compared to EtBr), small amounts of these dyes are generally mixed with DNA prior to separation. It is interesting to note that the sequence of mixing the dyes and DNA samples affects the electropherogram patterns. The fluorescence enhancements upon complexation with DNA are 1100- and 3200-fold for TOTO-1 and YOYO-1, respectively, which are much greater than 40 -fold of using EthD [56].

SY-TO series are relatively low-affinity nucleic acid stains and have been used for labeling DNA and RNA. Free SYTO dyes are weakly fluorescent (quantum yields $<0.01$ ), but become strongly fluorescent (quantum yields $>0.4$ ) upon binding to DNA. In this series, SYTOX Orange stain provides the best sensitivity for dsDNA, with a 500-fold lower LOD compared to commonly used EtBr and PI [60]. However they provide less sensitivity for DNA when compared to TOTO series. As a result, their use for DNA analysis by CE is not as popular as the TOTO series.

\section{Analysis of proteins}

The analysis of proteins is of importance because there is always an urgent need to understand how they are responsible for cellular structure and function. Proteomics is a large-scale protein analysis and has emerged as an important field to study protein function by examining the actions of proteins as part of a system or process. Although the study has been heavily relied on two-dimensional gel electrophoresis, the combination of high-performance liquid chromatography, CE, and mass spectrometry has provided an alternative tool. In addition to the separation based on the sieving mechanism, several different approaches in $\mathrm{CE}$ have been developed for 
the separation of proteins, including capillary zone electrophoresis, capillary isoelectric focusing, and so on [61-63].

The analysis of proteins by CE using UV absorption at $280 \mathrm{~nm}$ is common, but it suffers from low sensitivity (LODs only at the level of sub- $\mu M$ to $\mu M)$. Unlike DNA, proteins cannot be amplified by PCR, and thus highly sensitive detection systems are more demanded. LIF is highly sensitive and is certainly in the right place for trace analysis of proteins. Using an argon ion laser at $275 \mathrm{~nm}$, the LODs for proteins are down to $\mathrm{n} M$ to $\operatorname{sub}-\mathrm{n} M$, which allows the analyses of proteins such as hemoglobin and carbonic anhydrase in single cells [64]. The detection of single enzyme molecules has been achieved via a technique based on CE-LIF in conjunction with on-line enzyme reaction using an argon UV laser at $360 \mathrm{~nm}$ [65]. However the costs of the lasers and maintenance remain a big issue for most of labs. In addition, these techniques can only work for some proteins that have native fluorescence and/or substrates that react with enzymes to produce fluorescent products or to use up fluorescent substances.

When using a $\mathrm{He}-\mathrm{Ne}$ laser, most proteins have to be labeled with highly fluorescent substances such as rhodamine and cyanine families or non-fluorescent molecules such as SYPRO Red, 9-diethylamino-5Hbenzo $[a]$ phenoxazine-5-one (Nile Red), and albumin blue 580 (AB 580) that form stable and highly fluorescent complexes with proteins [66-71]. Generally, the reactions between these non-fluorescent dyes and proteins are faster and mostly the fluorescence intensities of thus formed complexes are $\mathrm{pH}$ independent [72]. More recently, Molecular Probes has commercialized Alexa Fluor family, which is highly photostable, bright, and water soluble, for the analysis of proteins [73,74].

\subsection{Rhodamine and cyanine families}

Prior to separation, these dyes are attached to proteins through covalent bonding. Attempts have made to accelerate the reaction speed, to increase product yield as well as quantum efficiency, and to prevent loss of the activity of proteins after derivatization. As a result, there have been so many derivatives of these dyes in the market for different purpose. Tetramethylrhodamine (TMR) is a widely used fluorescent dye because it is stable and highly fluorescent [66]. The fluorescence quantum efficiencies almost double after TMR-labeled proteins are denatured by guanidine hydrochloride. Staphylococcal enterotoxin B (SEB) labeled with TRITC was analyzed by $\mathrm{CE}$ using a competitive assay, with an LOD of approximately $300 \mathrm{fg}$ [67]. Recently, Krylov et al. demonstrated the use of disaccharide labeled with TMR for a metabolism study in single cells [75] and the use of TMR for the analysis of HT 29 cell using a multipurpose single-cell injector [76]. Lissamine 20 is water soluble and reacts rapidly $\left(t_{1 / 2} \sim\right.$ $10 \mathrm{~min}$ ) with proteins at a ratio of $2: 1$ by acylation of free amino acids at their N-termini or in amino acid residues such as lysine [77]. CE-LIF provides the LOD of $3.9 \cdot 10^{-19} \mathrm{~mol}$ for insulin labeled with Lissamine 20, which allows the investigation of the proteolysis kinetic of insulin by trypsin [78].

A number of $\mathrm{Cy}$ dyes have been tested for the analysis of proteins, including Cy3, Cy3.5, Cy5, and $\mathrm{Cy} 7$, which have maximum excitation wavelengths at 550, 581, 650, and 678, respectively [68]. Cy5, with a very reactive succinimidyl ester group, quickly interacts with an aliphatic primary amine or hydroxyl group at neutral or alkaline $\mathrm{pH}$ and has been used for the analysis of proteins [79-81]. This advantage allows one to perform immunoassay when using antibodies or antigens labeled with Cy5 or to conduct enzymatic assay using substrates labeled with Cy5. Together with high resolving power of CE and high specificity of molecular recognition, these methods are highly specific and suitable for exploring protein interactions in very complicated biological systems. Attiya et al. developed a CE immunoassay method for the determination of the concentration of ovalbumin (Ov), with an LOD of $173 \mathrm{n} M$ [82]. Wu and Tsai demonstrated the use of a synthetic peptide (substrate) labeled with Cy5 for the measurement of the activity of kinase $\mathrm{C}$ and $\mathrm{Src}$ kinase [83].

\subsection{Solvatochromic dyes}

Solvatochromic dyes change color according to the polarity of the liquid in which they are dissolved. With such a characteristic, a number of solvatochromic dyes including SYPRO Red and Nile Red 
have been applied to the analysis of proteins in the presence of sodium dodecyl sulfate (SDS) $[69,70,84]$. The interactions of proteins with SYPRO Red and Nile Red are fast and the fluorescence intensities of the complexes are much stronger compared to the free dyes. Although the fluorescence intensity of the protein complexes increases in the presence of SDS, a dramatic increase in the fluorescence background when the free dyes are distributed in SDS micelles. Thus to minimize the fluorescent background, the concentration of SDS in the background electrolyte must be kept lower than its critical micelle concentration [84]. Furthermore, the effect of SDS on changing the mobility of proteins must be considered in order to achieve better resolution. Using $8 \%$ linear polyacrylamide containing $0.05 \%$ SDS, the LOD values for the standard proteins labeled with SYPRO Red are at the pmol level [69]. From our own experience, the sensitivity for proteins can be improved by several-fold by adding suitable amounts of salts like $5 \mathrm{mM} \mathrm{NaCl}$ in the background electrolyte [85].

Nile Red is highly insoluble in aqueous solution and generally prepared in organic solvents such as dimethyl sulfoxide. It has been used for protein analyses by slab gel electrophoresis and CE, with LODs down to $n M$ [84]. Although Nile Red provides excellent sensitivity, problems such as loss of resolution and irreproducibility were found due to adsorption of dyes on the capillary wall and photobleaching. The use of relatively high amount of organic solvent also causes poor sensitivity. Compared to Nile Red, merocyanine 540 (MC 540) is more suitable for the analysis of proteins by CELIF, simply because of its better aqueous solubility. MC 540 belongs to the family of benzoxazol merocyanine dyes with heterocyclic aromatic groups linked by a polymethine chain. It has been known that its optical characteristics are very sensitive to the changes in environmental factors, such as viscosity, temperature, and polarity, and the quantum efficiency of MC 540 in aprotic solvent is greater because MC 540 tends to form dimers and undergoes a faster photoisomerization in protic solvent. MC 540 is a weak fluorescent dye in aqueous solution and forms highly fluorescent complexes with proteins. Recently, Chiu et al. have taken these advantages to perform the analysis of proteins by CE-LIF [85]. By simply adding MC 540 in the buffer electrolyte, they analyzed several proteins including hemoglobin, conalbumin, bovine serum albumin, ovalbumin with the LODs at the level of $\mathrm{n} M$. Please note that MC 540 is very unstable at high $\mathrm{pH}(>9.0)$ or at high concentrations of Tris buffer $(>200 \mathrm{mM})$.

\subsection{Albumin blue series}

Albumin blue (AB) dyes, including $\mathrm{AB} 580, \mathrm{AB}$ 633 and $A B$ 670, are non-fluorescent and highly specific for albumins. They quickly bind to albumins in a specific way to undergo dramatic fluorescence enhancement [71]. $\mathrm{AB} 633$ and $\mathrm{AB} 670$ provide the LOD at the level of $\mathrm{n} M$ for albumins and have been used to determine the concentration of human serum albumin (HSA) in urine samples [86]. However, the limit stability of $\mathrm{AB} 633$ and $\mathrm{AB} 670$ solutions obviates their routine application. In order to overcome this disadvantage, AB 580 has been developed and become more popular for the analysis of albumins $[87,88]$. The maximum excitation wavelength and emission wavelength for albumin $-\mathrm{AB}$ 580 complexes are 593 and $608 \mathrm{~nm}$, respectively. Tseng et al. developed a method for the analysis of HSA by CE-LIF using AB 580, with an LOD of $11.1 \mathrm{n} M$ [88]. Using this method, the concentrations of HSA in urine and blood cells from a normal male were determined without any pretreatment process, with the results of $5.2 \pm 0.2 \mathrm{mg} / 1$ and about $8.2 \pm 0.2$ zmol/cell. Owing to highly specificity of the albumin blue series to albumins, their use has been limited.

\subsection{Phycobiliproteins}

Phycobiliproteins are water soluble and highly fluorescent proteins over a wide $\mathrm{pH}$ range and are produced by cyanobacteria (blue-green algae) and red algae [89]. Three major phycobiliproteins are allophycocyanins (APCs), phycocyanins (PCs), and phycoerythrins (PEs), which have excitation and emission maxima at 652/660, 615/647, and $565(494) / 575 \mathrm{~nm}$, respectively. Viskari and coworkers showed that the LODs for three phycobiliproteins are down to $\mathrm{p} M$ using a $\mathrm{He}-\mathrm{Ne}$ laser $[90,91]$. With high quantum efficiency $(\sim 1.0)$, these proteins labeled with biotin, avidin, antibodies 
or antigens are commonly used for the analysis of important solutes in CE [92]. One main drawback of using these proteins compared to small organic dyes is that the steric effect might occur, leading to loss of activity or recognition of biomolecules.

\section{Conclusions}

CE-LIF has emerged as a premier technique for rapid, high-resolution, and sensitive analysis of solutes of biological interests. To achieve better sensitivity, the wavelength of the laser used should match the peak of absorbance of the analyte. Lasers with different wavelengths, such as $\mathrm{Ar}^{+}, \mathrm{Nd}: \mathrm{YAG}$, $\mathrm{He}-\mathrm{Cd}$, and $\mathrm{He}-\mathrm{Ne}$ lasers, have been employed in $\mathrm{CE}$ for the analyses of numerous analytes or analytes derivatized with different dyes. With the advantages of high-throughput and sensitivity, it is our belief that CE and CAE in conjunction with LIF will still play an important role in the analysis of biopolymers. Although we only reviewed the analysis of DNA and proteins by CE-LIF and briefly summarized some results in Table 1, some formats addressed in this article have also been tested in electrophoresis on a chip with varying degree of success [93-96]. With the capability of integration and rapidity, we are sure that the so-called lab-on-a chip techniques will soon become popular in the scientific community. Compared to CE, highly sensitive detection modes, such as LIF and absorption detection methods based on thermal lens effect, and/ or approaches like on-line concentration techniques are highly demanded for chip electrophoresis due to small sample volumes (fl) and short optical lengths. Efforts to synthesize dyes that have high quantum efficiencies at long wavelengths and can quickly, efficiently, and/or selectively react with biopolymers will still be made. In the end, we should mention that diode lasers or light emitting diodes will be more widely accepted in CE and electrophoresis on a chip because of their low costs, long lifetime, and compact [97-100].

\section{Acknowledgements}

This work was supported by the National Science Council of the Republic of China under contract

Table 1

Summary of the long-wavelength dyes used for DNA and proteins

\begin{tabular}{|c|c|c|c|c|c|c|c|c|}
\hline Reagent & Molecular formula & Molecular mass & $\lambda_{\mathrm{ex}} / \lambda_{\mathrm{em}}(\mathrm{nm})$ & Compound & $K_{\mathrm{b}}\left(M^{-1}\right)$ & Quantum yield & LOD & Ref. \\
\hline AB 580 & $\mathrm{C}_{14} \mathrm{H}_{8} \mathrm{ClKN}_{4}$ & 306.8 & $593 / 608$ & HSA & $4.2 \cdot 10^{7}$ & NG & $11.1 \mathrm{n} M$ & [88] \\
\hline $\mathrm{AB} 633$ & $\mathrm{C}_{18} \mathrm{H}_{12} \mathrm{~N}_{5} \mathrm{Cl}$ & 333.7 & $620 / 635$ & HSA & $1.3 \cdot 10^{7}$ & NG & $0.2 \mathrm{mg} / 1$ & [71] \\
\hline $\mathrm{AB} 670$ & $\mathrm{C}_{23} \mathrm{H}_{21} \mathrm{~N}_{5} \mathrm{OCl}_{2}$ & 454.4 & $669 / 687$ & HSA & $1.8 \cdot 10^{7}$ & NG & $0.2 \mathrm{mg} / 1$ & [71] \\
\hline BPB & $\mathrm{C}_{19} \mathrm{H}_{9} \mathrm{Br}_{4} \mathrm{NaO}_{5} \mathrm{~S}$ & 692.0 & $592 / 625$ & HSA & $1.5 \cdot 10^{6}$ & NG & $89.2 \mathrm{n} M$ & [88] \\
\hline Су5 & $\mathrm{C}_{45} \mathrm{H}_{54} \mathrm{KN}_{4} \mathrm{O}_{14} \mathrm{~S}_{2}$ & 978.1 & $649 / 670$ & Ov & NG & $>0.3$ & $173 \mathrm{n} M$ & [82] \\
\hline $\mathrm{EtBr}$ & $\mathrm{C}_{21} \mathrm{H}_{20} \mathrm{BrN}_{3}$ & 394.3 & $518 / 605$ & DNA fragments & $1.5 \cdot 10^{5}$ & $>0.2$ & $9.05 \mathrm{ng} / \mathrm{ml}$ & [53] \\
\hline EthD-1 & $\mathrm{C}_{46} \mathrm{H}_{50} \mathrm{Cl}_{4} \mathrm{~N}_{8}$ & 856.7 & $528 / 580$ & DNA fragments & $2.0 \cdot 10^{8}$ & $>0.6$ & NG & [58] \\
\hline EthD-2 & $\mathrm{C}_{51} \mathrm{H}_{60} \mathrm{I}_{4} \mathrm{~N}_{8}$ & 1292.7 & $535 / 624$ & DNA fragments & $1.0 \cdot 10^{9}$ & $>0.6$ & $3.9 \cdot 10^{-16} M$ & [57] \\
\hline Lissamine 20 & $\mathrm{C}_{27} \mathrm{H}_{29} \mathrm{ClN}_{2} \mathrm{O}_{6} \mathrm{~S}_{2}$ & 577.1 & $556 / 576$ & Insulin & NG & NG & $35 \mathrm{p} M$ & [78] \\
\hline Nile Red & $\mathrm{C}_{20} \mathrm{H}_{18} \mathrm{~N}_{2} \mathrm{O}_{2}$ & 318.3 & $550 / 609$ & BSA & NG & NG & NG & [84] \\
\hline PI & $\mathrm{C}_{27} \mathrm{H}_{34} \mathrm{I}_{2} \mathrm{~N}_{4}$ & 668.4 & $535 / 617$ & DNA fragments & $1.0 \cdot 10^{8}$ & NG & $37.4 \mathrm{pg} / \mu \mathrm{l}$ & [60] \\
\hline POPO-3 & $\mathrm{C}_{45} \mathrm{H}_{58} \mathrm{I}_{4} \mathrm{~N}_{6} \mathrm{O}_{2}$ & 1222.6 & $534 / 570$ & DNA fragments & $1.5 \cdot 10^{8}$ & $>0.9$ & $1.1 \cdot 10^{-21} \mathrm{~mol}$ & [47] \\
\hline Rhodamine & $\mathrm{C}_{30} \mathrm{H}_{34} \mathrm{~N}_{4} \mathrm{O}_{4}$ & 514.6 & $555 / 580$ & DNA fragments & NG & NG & $1.0 \cdot 10^{-21} \mathrm{~mol}$ & [43] \\
\hline SYPRO Red & $\mathrm{NG}^{\mathrm{a}}$ & 650 & $547 / 631$ & BSA & NG & $>0.4$ & $73 \mathrm{p} M$ & [69] \\
\hline SYTO 25 & NG & 450 & $521 / 556$ & DNA fragments & $5.0 \cdot 10^{7}$ & $>0.4$ & $2.6 \mathrm{pg} / \mu \mathrm{l}$ & [60] \\
\hline SYTO 82 & NG & 350 & $541 / 560$ & DNA fragments & $2.5 \cdot 10^{7}$ & $>0.4$ & $1.4 \mathrm{pg} / \mu \mathrm{l}$ & [60] \\
\hline SYTOX Orange & NG & 500 & $547 / 570$ & DNA fragments & $5.8 \cdot 10^{8}$ & $>0.4$ & $0.072 \mathrm{pg} / \mu \mathrm{l}$ & [60] \\
\hline Texas Red & $\mathrm{C}_{37} \mathrm{H}_{36} \mathrm{~N}_{4} \mathrm{O}_{8} \mathrm{~S}_{2}$ & 728.8 & $595 / 615$ & DNA fragments & NG & NG & NG & [44] \\
\hline YOYO-1 & $\mathrm{C}_{49} \mathrm{H}_{58} \mathrm{I}_{4} \mathrm{~N}_{6} \mathrm{O}_{2}$ & 1270.6 & $491 / 509$ & DNA fragments & $6.0 \cdot 10^{8}$ & $>0.9$ & $5.0 \cdot 10^{-21} \mathrm{~mol}$ & [47] \\
\hline YOYO-3 & $\mathrm{C}_{53} \mathrm{H}_{62} \mathrm{I}_{4} \mathrm{~N}_{6} \mathrm{O}_{2}$ & 1322.7 & $612 / 631$ & DNA fragments & $1.5 \cdot 10^{8}$ & $>0.9$ & $1.9 \cdot 10^{-21} \mathrm{~mol}$ & [47] \\
\hline
\end{tabular}

\footnotetext{
${ }^{\mathrm{a}}$ Not given.
} 
Nos. NSC 90-2113-M002-058 and NSC 90-2113M002-052.

\section{References}

[1] D.B. Craig, E. Arriaga, J.C.Y. Wong, H. Lu, N.J. Dovichi, Anal. Chem. 70 (1998) 39A.

[2] H. Li, G. Xue, E.S. Yeung, Anal. Chem. 73 (2001) 1537.

[3] K. Klepárník, Z. Malá, P. Boček, Electrophoresis 22 (2001) 783.

[4] D.T. Chiu, S.J. Lillard, R.H. Scheller, R.N. Zare, S.E. Rodriguez-Cruz, E.R. Williams, O. Orwar, M. Sandberg, J.A. Lundqvist, Science 279 (1998) 1190.

[5] R.T. Kennedy, J.E. Thompson, T.W. Vickroy, J. Neurosci. Methods 114 (2002) 39.

[6] C.E. MacTaylor, A.G. Ewing, Electrophoresis 19 (1998) 1234.

[7] W.-L. Tseng, H.-T. Chang, J. Chromatogr. A 924 (2001) 93.

[8] M.T. Bowser, R.T. Kennedy, Electrophoresis 22 (2001) 3668.

[9] M. Girod, D.W. Armstrong, Electrophoresis 23 (2002) 2048.

[10] L. Berti, I.L. Medintz, J. Tom, R.A. Mathies, Bioconjug. Chem. 12 (2001) 493.

[11] N. Zhang, H. Tan, E.S. Yeung, Anal. Chem. 71 (1999) 1138.

[12] E.S. Yeung, P. Wang, W. Li, R.W. Giese, J. Chromatogr. 608 (1992) 73.

[13] L. Hernandez, J. Escalona, N. Joshi, N. Guzman, J. Chromatogr. 559 (1991) 183.

[14] J.A. Taylor, E.S. Yeung, Anal. Chem. 64 (1992) 1741.

[15] D.C. Nguyen, R.A. Keller, J.H. Jett, J.C. Martin, Anal. Chem. 59 (1987) 2158.

[16] H.J. Issaq, K.C. Chan, Electrophoresis 16 (1995) 467.

[17] W.-L. Tseng, H.-T. Chang, Anal. Chem. 72 (2000) 4805.

[18] E.S. Yeung, J. Chromatogr. A 830 (1999) 243.

[19] L.J. Jin, B.C. Giordano, J.P. Landers, Anal. Chem. 73 (2001) 4994.

[20] R.P. Haugland, Handbook of Fluorescent Probes and Research Chemicals, 6th ed., Molecular Probes, Eugene, OR, 1996.

[21] J.C.M. Waterval, H. Lingeman, A. Bult, W.J.M. Underberg, Electrophoresis 21 (2000) 4029.

[22] X. Páez, L. Hernández, Biopharm. Drug Dispos. 22 (2001) 273.

[23] L. Mitnik, M. Novotny, C. Felten, S. Buonocore, L. Koutny, D. Schmalzing, Electrophoresis 22 (2001) 4104.

[24] S. Hu, N.J. Dovichi, Anal. Chem. 74 (2002) 2833.

[25] W.J.M. Underberg, J.C.M. Waterval, Electrophoresis 23 (2002) 3922.

[26] G.W. Slater, C. Desruisseaux, S.J. Hubert, J.-F. Mercier, J. Labrie, J. Boileau, F. Tessier, M.P. Pépin, Electrophoresis 21 (2000) 3873.

[27] C. Heller, Electrophoresis 22 (2001) 629.

[28] S.N. Krylov, N.J. Dovichi, Anal. Chem. 72 (2000) 111R.

[29] J.R. Scherer, I. Kheterpal, A. Radhakrishnan, W.W. Ja, R.A. Mathies, Electrophoresis 20 (1999) 1508.

[30] Y. Zhang, H. Tan, E.S. Yeung, Anal. Chem. 71 (1999) 5018.
[31] H. Zhou, A.W. Miller, Z. Sosic, B. Buchholz, A.E. Barron, L. Kolter, B.L. Karger, Anal. Chem. 72 (2000) 1045.

[32] E.S. Mansfield, M. Vainer, D.W. Harris, P. Gasparini, X. Estivill, S. Surrey, P. Fortina, J. Chromatogr. A 781 (1997) 295.

[33] G. Mátyás, C. Giunta, B. Steinmann, J.P. Hossle, R. Hellwig, Hum. Mutat. 19 (2002) 58.

[34] W.N. Vreeland, R.J. Meagher, A.E. Barron, Anal. Chem. 74 (2002) 4328.

[35] O. Salas-Solano, E. Carrilho, L. Kotler, A.W. Miller, W. Goetzinger, Z. Sosic, B.L. Karger, Anal. Chem. 70 (1998) 3996.

[36] H. He, B.A. Buchholz, L. Kolter, A.W. Miller, A.E. Barron, B.L. Karger, Electrophoresis 23 (2002) 1421.

[37] A. Hanning, J. Westberg, J. Roeraade, Electrophoresis 21 (2000) 3290.

[38] M. Hahn, J. Wilhelm, A. Pingoud, Electrophoresis 22 (2001) 2691.

[39] L. Berti, I.L. Medintz, J. Tom, R.A. Mathies, Bioconjug. Chem. 12 (2001) 493.

[40] U. Lieberwirth, J. Arden-Jacob, K.H. Drexhage, D.P. Herten, R. Müller, M. Neumann, A. Schulz, S. Siebert, G. Sagner, S. Klingel, M. Sauer, J. Wolfrum, Anal. Chem. 70 (1998) 4771.

[41] H. He, L.B. McGown, Anal. Chem. 72 (2000) 5865.

[42] B.K. Nunnally, H. He, L.-C. Li, S.A. Tucker, L.B. McGown, Anal. Chem. 69 (1997) 2392.

[43] J.Z. Xing, J. Lee, S.A. Leadon, M. Weinfeld, X.C. Le, Methods 22 (2000) 157.

[44] H. Arakawa, A. Tsuji, M. Maeda, M. Kamahori, H. Kambara, J. Pharm. Biomed. Anal. 15 (1997) 1537.

[45] W.-L. Tseng, M.-M. Hsieh, S.-J. Wang, C.-C. Huang, Y.-C. Lin, P.-L. Chang, H.-T. Chang, J. Chromatogr. A 927 (2001) 179.

[46] H. Zhu, S.M. Clark, S.C. Benson, H.S. Rye, A.N. Glazer, R.A. Mathies, Anal. Chem. 66 (1994) 1941.

[47] D. Figeys, E.A. Arriaga, A. Renborg, N.J. Dovichi, J. Chromatogr. A 669 (1994) 205.

[48] Y. Kim, M.D. Morris, Anal. Chem. 66 (1994) 1168.

[49] J. Skeidsvoll, P.M. Ueland, Anal. Biochem. 231 (1995) 359.

[50] W.-L. Tseng, M.-M. Hsieh, S.-J. Wang, H.-T. Chang, J. Chromatogr. A 894 (2000) 219.

[51] O. de Carmejane, J.J. Schwinefus, S.-C. Wang, M.D. Morris, J. Chromatogr. A 849 (1999) 267.

[52] J.L. Zabzdyr, S.J. Lillard, Anal. Chem. 73 (2001) 5771.

[53] C.-C. Huang, M.-M. Hsieh, T.-C. Chiu, Y.-C. Lin, H.-T. Chang, Electrophoresis 22 (2001) 4328.

[54] H.-S. Chen, H.-T. Chang, J. Chromatogr. A 853 (1999) 337.

[55] M.-F. Huang, C.-E. Hsu, W.-L. Tseng, Y.-C. Lin, H.-T. Chang, Electrophoresis 22 (2001) 2281.

[56] A.N. Glazer, H.S. Rye, Nature 359 (1992) 859.

[57] W.G. Tan, D.L.J. Tyrrell, N.J. Dovichi, J. Chromatogr. A 853 (1999) 309.

[58] H.S. Rye, S. Yue, D.E. Wemmer, M.A. Quesada, R.P. Haugland, R.A. Mathies, A.N. Glazer, Nucleic Acids Res. 20 (1992) 2803.

[59] X. Yan, W.K. Grace, T.M. Yoshida, R.C. Habbersett, N. Velappan, J.H. Jett, R.A. Keller, B.L. Marrone, Anal. Chem. 71 (1999) 5470. 
[60] X. Yan, W. Hang, V. Majidi, B.L. Marrone, T.M. Yoshida, J. Chromatogr. A 943 (2002) 275.

[61] Y. Shen, R.D. Smith, J. Microcol. Sep. 12 (2000) 135.

[62] V. Dolník, Electrophoresis 20 (1999) 3106.

[63] S.H. Kang, X. Gong, E.S. Yeung, Anal. Chem. 72 (2000) 3014.

[64] S.J. Lillard, E.S. Yeung, R.M.A. Lautamo, D.T. Mao, J. Chromatogr. A 718 (1995) 397.

[65] M.J. Eggertson, D.B. Craig, Biomed. Chromatogr. 13 (1999) 516.

[66] K. Shimura, K. Kamiya, H. Matsumoto, K. Kasai, Anal. Chem. 74 (2002) 1046.

[67] M.T. Lam, C.A. Boulet, X.C. Le, Anal. Chim. Acta 457 (2002) 21.

[68] H.J. Gruber, C.D. Hahn, G. Kada, C.K. Riener, G.S. Harms, W. Ahrer, T.G. Dax, H.-G. Knaus, Bioconjug. Chem. 11 (2000) 696.

[69] M.D. Harvey, D. Bandilla, P.R. Banks, Electrophoresis 19 (1998) 2169.

[70] F.J. Alba, A. Bermúdez, J.-R. Daban, Electrophoresis 22 (2001) 399.

[71] M.A. Kessler, O.S. Wolfbeis, Anal. Biochem. 200 (1992) 254.

[72] E.D. Moody, P.J. Viskari, C.L. Colyer, J. Chromatogr. B 729 (1999) 55.

[73] I. Biran, D.R. Walt, Anal. Chem. 74 (2002) 3046.

[74] K. Macounová, C.R. Cabrera, P. Yager, Anal. Chem. 73 (2001) 1627.

[75] S.N. Krylov, E.A. Arriaga, Z. Zhang, N.W.C. Chan, M.M. Palcic, N.J. Dovichi, J. Chromatogr. B 741 (2000) 31.

[76] S.N. Krylov, D.A. Starke, E.A. Arriaga, Z. Zhang, N.W.C. Chan, M.M. Palcic, N.J. Dovichi, Anal. Chem. 72 (2000) 872 .

[77] S.N. Smith, R.P. Steer, J. Photochem. Photobiol. A 139 (2001) 151.

[78] H.B. Lim, J.J. Lee, K.-J. Lee, Electrophoresis 16 (1995) 674.

[79] R.A. Evangelista, F.-T.A. Chen, J. Chromatogr. A 680 (1994) 587.

[80] R.B. Mujumdar, L.A. Ernst, S.R. Mujumdar, C.J. Lewis, A.S. Waggoner, Bioconjug. Chem. 4 (1993) 105.
[81] P. Jing, T. Kaneta, T. Imasaka, Electrophoresis 23 (2002) 550 .

[82] S. Attiya, T. Dickinson-Laing, J. Cesarz, R.D. Giese, W.E. Lee, D. Mah, D.J. Harrison, Electrophoresis 23 (2002) 750.

[83] W.-S. Wu, J.-L. Tsai, Anal. Biochem. 269 (1999) 423.

[84] J.-R. Daban, S. Bartolomé, M. Samsó, Anal. Biochem. 199 (1991) 169.

[85] T.-C. Chiu, Y.-W. Lin, C.-C. Huang, A. Chrambach, H.-T. Chang, Electrophoresis 24 (2003) in press.

[86] M.A. Kessler, M.R. Hubmann, B.A. Dremel, O.S. Wolfbeis, Clin. Chem. 38 (1992) 2089.

[87] M.A. Kessler, A. Meinitzer, O.S. Wolfbeis, Anal. Biochem. 248 (1997) 180.

[88] W.-L. Tseng, T.-C. Chiu, J.-M. Weng, H.-T. Chang, J. Liq. Chromatogr. Rel. Technol. 24 (2001) 2971.

[89] A.N. Glazer, J. Appl. Phycol. 6 (1994) 105.

[90] P.J. Viskari, C.S. Kinkade, C.L. Colyer, Electrophoresis 22 (2001) 2327.

[91] P.J. Viskari, C.L. Colyer, J. Chromatogr. A 972 (2002) 269.

[92] K. Peck, L. Stryer, A.N. Glazer, R.A. Mathies, Proc. Natl. Acad. Sci. USA 86 (1989) 4087.

[93] J. Ferrance, J.P. Landers, Luminescence 16 (2001) 79.

[94] J. Khandurina, A. Guttman, J. Chromatogr. A 943 (2002) 159.

[95] P.-A. Auroux, D. Iossifidis, D.R. Reyes, A. Manz, Anal. Chem. 74 (2002) 2637.

[96] I.L. Medintz, B.M. Paegel, R.G. Blazej, C.A. Emrich, L. Berti, J.R. Scherer, R.A. Mathies, Electrophoresis 22 (2001) 3845.

[97] G. Jiang, S. Attiya, G. Ocvirk, W.E. Lee, D.J. Harrison, Biosens. Bioelectron. 14 (2000) 861.

[98] J.E. Melanson, C.A. Boulet, C.A. Lucy, Anal. Chem. 73 (2001) 1809.

[99] E.M. McCorquodale, C.L. Colyer, Electrophoresis 22 (2001) 2403.

[100] M.L. Chabinyc, D.T. Chiu, J.C. McDonald, A.D. Stroock, J.F. Christian, A.M. Karger, G.M. Whitesides, Anal. Chem. 73 (2001) 4491. 